\title{
MIND MAP Value Proposition Design
}

Arveandro Arzetta 2440006381 Binus Malang arveandro.arzetta@binus.ac.id
Referensi:(Alexander Osterwalder,Yves

Pigneur,Greg Bernanda \& Alan Smith(2014)Value

Proposition design,John Wiley \& Sons,Inc)

Dosen Pembimbing: Agung Purnomo

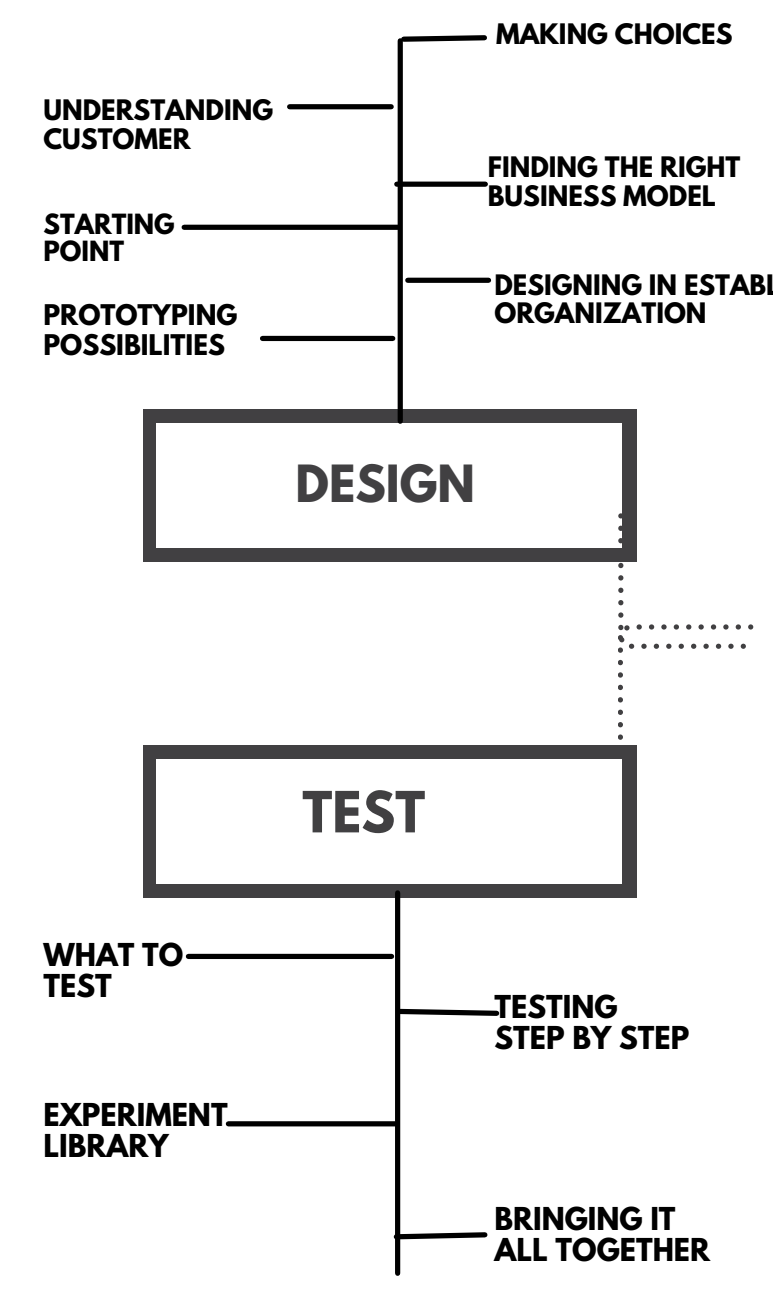

\section{VALUE PROPOSITION DESIGN}

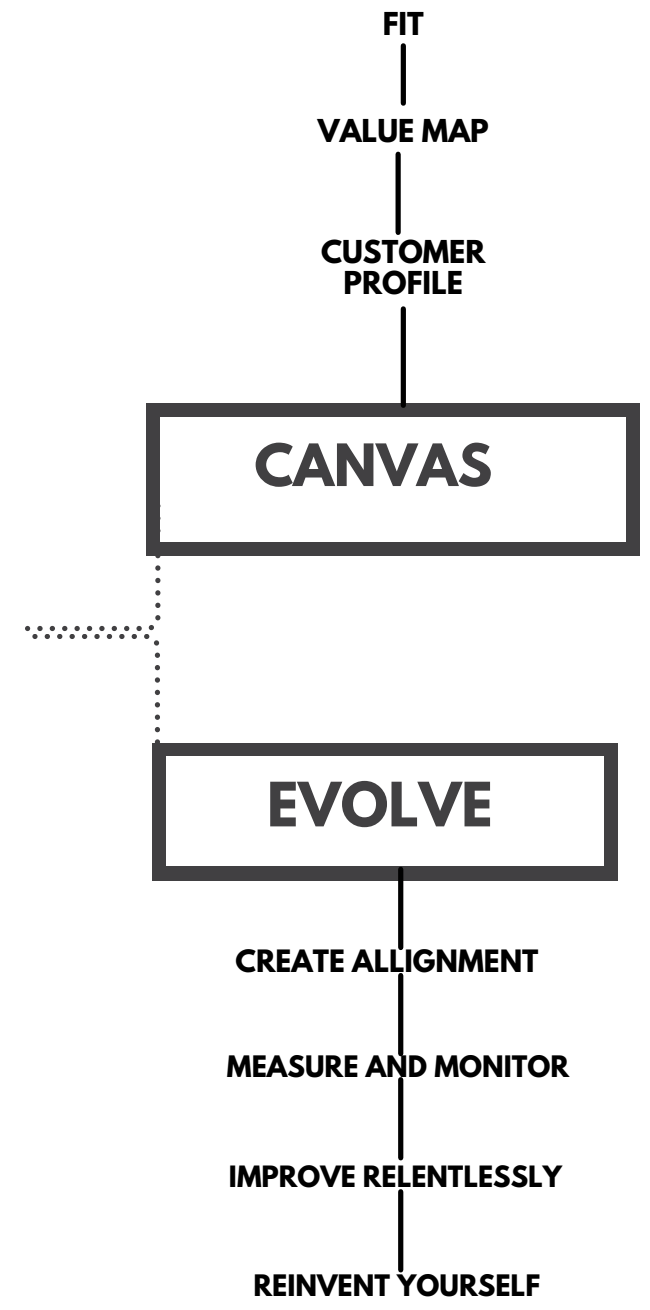

